\title{
Watershed zonation approach for tractably quantifying above-and- belowground watershed heterogeneity and functions
}

Haruko M. Wainwright ${ }^{1,2}$, Sebastian Uhlemann ${ }^{1}$, Maya Franklin ${ }^{1}$, Nicola Falco ${ }^{1}$, Nicholas J. Bouskill ${ }^{1}$, Michelle Newcomer $^{1}$, Baptiste Dafflon ${ }^{1}$, Erica Woodburn ${ }^{1}$, Burke J. Minsley ${ }^{3}$, Kenneth H. Williams ${ }^{1,4}$, 5 Susan S. Hubbard ${ }^{1}$

${ }^{1}$ Lawrence Berkeley National Laboratory, Berkeley, CA 94720, USA

${ }^{2}$ University of California, Berkeley, CA 94720, USA

${ }^{3}$ U.S. Geological Survey, Denver, CO 80225, USA

${ }^{4}$ Rocky Mountain Biological Laboratory, Crested Butte, CO, 81224, USA

10 Correspondence to: Haruko M. Wainwright (hmwainwright@lbl.gov)

\begin{abstract}
In this study, we develop a watershed zonation approach for characterizing watershed organization and function in a tractable manner by integrating multiple spatial data layers. Recognizing the coupled ecohydrogeological-biogeochemical interactions that occur across bedrock through canopy compartments of a watershed, we hypothesize that (1) suites of above/belowground properties co-varying with each other, (2) hillslopes are representative units for capturing watershed-scale

15 heterogeneity, (3) remote sensing data layers and clustering methods can be used to identify watershed hillslope zones having unique distributions of bedrock-through-canopy properties relative to neighboring parcels, and (4) property suites associated with the identified zones can be used to understand zone-based functions, such as response to early snowmelt or drought, and associated solute exports to the river. We demonstrate this concept using unsupervised clustering methods that synthesizes airborne remote sensing data (LiDAR, hyperspectral, and electromagnetic surveys) along with satellite and streamflow data collected in the East River Watershed, Crested Butte, Colorado, USA. Results show that, (1) hillslope-average elevation and slope are significantly correlated with near-surface bedrock electrical resistivity (top $20 \mathrm{~m}$ ), (2) elevation and aspect are independent controls on plant and snow signatures, (3) the correlation between hillslope-averaged above- and below- ground properties are significantly higher than pixel-by-pixel correlation and (4) K-means, hierarchical clustering, and Gaussian mixture clustering methods generate similar zonation patterns across the watershed. Using independently collected data, it is shown that the identified zones provide information about zone-based watershed functions, including foresummer drought sensitivity and river nitrogen exports. The approach is expected to be extensible to other sites and generally useful for guiding the selection of hillslope experiment locations and informing model parameterization.
\end{abstract}




\section{Introduction}

30 Predictive understanding of watershed functions is often hindered by the heterogeneous and multiscale fabric of watersheds (e.g., Peters-Lidard et al., 2017). Heterogeneity exists within each of the watershed compartments, including aboveground compartments (i.e., plant species distribution and plant dynamics, topography) and belowground compartments (i.e., soil and bedrock structures/properties). Such watershed patterns influence ecohydrological and biogeochemical processes, which in turn affect watershed functions and create emerging patterns as feedback (Sivapalan, 2006). Since watersheds consist of

35 diverse biotic and abiotic compartments, watershed functions include diverse signatures, including hydrological (i.e., partition, storage, and release of water), ecological (e.g., species adaptation, productivity), and geochemical (e.g., nutrient cycling, solute export) signatures (Sivapalan, 2006; Wagener et al., 2007). There is a multiscale nature of heterogeneity such that different processes have different characteristic scales. Studies have suggested that the relevant spatial scale for hydrological heterogeneity governing fluxes is on the order of $100 \mathrm{~m}$ (Wood et al., 2011), whereas for soil moisture it is on the order of several or several tens of meters (e.g., Engstrom et al., 2005; Wainwright et al., 2015), and one meter or less for biogeochemical dynamics (e.g., Burt and Pinay, 2005; Groffman et al., 2009).

There have been extensive studies to investigate how the heterogeneous watershed organization influences water, energy, and nutrient cycling and their fluxes (e.g., Peters-Lidard et al., 2017). There are two directions for tackling this problem: a bottom-

45 up Newtonian approach or a top-down Darwinian approach. The Newtonian approach is a reductionist approach to describe a system by a set of mass/energy/momentum conservation equations with spatially variable parameters. Recently, integrated hydrological and reactive transport models have been successfully implemented to describe and predict watershed behaviors from hillslope to watershed and continental scales (e.g., Maxwell and Kollet, 2008; Li et al., 2017). In addition, the Hydrological Response Unit concept has been used to classify the landscapes based on spatial datasets (e.g., landcover types, elevation, and soil maps) and to parameterize hydrological models (Flugel, 1997; Aytaç, 2020). On the other hand, the Darwinian approach identifies rules or organizing principles governing spatial patterns of complex datasets, and defines watersheds as self-organized and co-evolved units by watershed functional traits (McDonnell et al., 2007). Catchment scaling and similarity concepts have been used to synthesize the catchment datasets across scales and to classify catchments (Wagener et al., 2007; Thompson et al., 2011; Sawicz et al., 2011; Krause et al. 2014).

In parallel, there have been significant advances recently in understanding and quantifying the watershed-scale heterogeneity of bedrock-to-canopy terrestrial compartments, which regulate water and nutrient cycling and their exports; particularly through the critical zone observatory (CZO) network (Brantley et al., 2017). In particular, Pelletier et al. (2018) have highlighted the control of slope aspects on ecosystem and critical-zone systems, finding that, for example, in water-limited

60 systems, the north-facing slopes have less evapotranspiration and hence higher soil moisture, deeper weathering, and larger nutrient retention in soil (e.g., Hinckley et al., 2014). Such advances are largely attributed to a variety of spatially extensive 
characterization technologies across bedrock-to-canopy compartments, which provide various patterns. High-resolution DEM from LiDAR have been applied to better understand the relationship between geomorphology and hydrology (Prancevic and Kirchner, 2019), as well as to measure snow depths and snow-water-equivalent (SWE) over a basin scale (Painter et al., 2016).

65 LiDAR data was also able to inform near-surface soil properties (Patton et al., 2018; Gillin et al., 2015), hydrological connectivity (Jensco et al., 2009) and biogeochemical hotspots (Duncan et al., 2013). In addition, hyperspectral remote sensing can map plant traits (e.g., Asner et al., 2015), leaf water contents (e.g., Colombo et al., 2008), leaf chemistry (e.g., Feilhauer, et al., 2015) and other properties, which are also proxies for soil biogeochemistry (Madritch et al., 2014). At the same time, geophysics has been extensively used to characterize the subsurface structure and to estimate soil and bedrock properties.

70 Surface geophysics has been used to measure bedrock depth, weathering zone thickness, and other properties (e.g., de Pasquale et al., 2019), contributing to hillslope-scale hydrological characterization and modeling. Surface ERT and seismic data have also revealed the influence of tectonic stresses and hydrological processes on bedrock fracturing and weathering (Rempe and Dietritch, 2014; St. Clair et al., 2015). Airborne geophysics - particularly airborne electromagnetic (EM) surveys-was originally developed for mineral exploration, but is now increasingly used for water-resources applications (e.g., Barfod et al.,

75 2018; Ball et al., 2020).

Despite these advancements, there are still challenges in associating watershed functions to heterogenous watershed patterns. It remains a challenge to integrate multitype and multiscale datasets, including ground-based point measurements and airborne or satellite remote-sensing datasets. Although the aboveground properties, such as topography and plant characteristics, can

80 be mapped over the watershed scale, the subsurface variability is still difficult to map over that scale, which is one of the biggest uncertainties in hydrology (Fan et al., 2019). In addition, even though hillslope-scale characterization and experiments (such as tracer tests) can be extremely useful for providing detailed information about watershed functions (e.g., Hinkley et al, 2014); it is difficult to select several hillslopes for such intensive characterization, or to gauge the representativeness of one hillslope for an entire watershed.

In this study, we develop and test the concept of a zonation approach for tractably characterizing the organization of a watershed based on multiple spatial data layers, and how these characteristic patterns aggregate to predict watershed functions. The clustering-based zonation approaches have emerged recently as effective spatial data integration methods that use spatial clustering to identify regions or zones that have unique distributions of heterogeneous properties and key functions relative to neighboring regions (Hubbard et al., 2013; Wainwright et al., 2015; Hermes et al., 2020). For watershed zonation, we consider a hillslope as a fundamental unit for watershed hydrology and element cycling, funneling water and elements from the ridge to the river (Fan et al., 2019), and also representing aspect controls on critical zones (Pelletier et al., 2018). We then hypothesize that (1) a suite of above/belowground compartments - plants, topography, soil, bedrock - are co-varying with each other through complex ecohydrological-biogeochemical interactions, (2) we can identify watershed subsystems or zones that have unique distributions of bedrock-through-canopy properties relative to neighboring parcels, and (3) the identified zones can 
capture the variability of key watershed functions. We demonstrate our approach using the airborne and spatial datasets collected in the East River watershed region near Crested Butte, Colorado, USA (Hubbard et al., 2018). We apply and compare multiple clustering methods to understand the characteristics, commonality, and differences among each method. Finally, we validate the zonation hypothesis based on the datasets that define key watershed functions, including drought sensitivity of plant productivity and water/nitrogen export.

\section{Site and Data}

We consider the domain of approximately $15 \mathrm{~km}$ by $15 \mathrm{~km}$ (Figure 1) near Gothic, Colorado, USA, which is the same area used in a recent study (Wainwright et al., 2020). As described in Hubbard et al. (2018), the domain includes four catchments, including the East River, Washington Gulch, Slate River and Coal Creek. It is part of the Elk Range in the Rocky Mountains, with elevation from $2800 \mathrm{~m}$ to $4000 \mathrm{~m}$ (Figure 1a). The major land-cover types (NLCD 2011) are rock outcrop (12\%), evergreen forest (29\%), deciduous forest (18\%), grassland (30\%), and woody wetland (6\%). Geology within the domain is diverse, including Paleozoic, Mesozoic, and Cenozoic sedimentary rocks (silt- and sandstones of the late Permian Maroon Formation; shales and sandstones of the upper Cretaceous Mancos Shale and Mesaverde group, respectively; silt- and

110 sandstones of the Eocene Wasatch Formation) and Miocene igneous intrusive rocks of predominantly granodioritic composition (Gaskill et al., 1991).

The spatial data layers include the USGS landcover map (NLCD 2011) and the digital geological map of Colorado (Green et al., 1992). Although a soil map is available, it is uniform except for outcrop regions, and therefore not informative for the

115 purposes of the current study. We assume that the geological map and topographic metrics can capture the variability of soil properties, since Gillin et al. (2015) documented strong correlations between topographic metrics and soil properties. In addition, we used four airborne datasets (Texts S1): an airborne electromagnetic (AEM) survey acquired in fall 2017 (Minsley and Ball, 2018; Uhlemann et al., submitted; Zamudio et al., 2020), LiDAR and hyperspectral data collected by the National Ecological Observation Network (NEON) team in June 2018 (Chadwick et al., 2020), and NASA Airborne Snow Observatory (ASO) data collected in April 2018 (doi.org/10.5067/M4TUH28NHL4Z).

To test the zonation hypothesis, we used datasets representing two key functions: foresummer drought sensitivity of plant productivity and river nitrogen export. The foresummer drought sensitivity map based on Landsat NDVI was developed by Wainwright et al. (2020) to represent the plant productivity responses to early snowmelt and subsequent drought conditions in

125 the early growing season. Since the satellite images were not used in clustering, they were considered independent datasets. In addition, the annual discharge and nitrogen export are computed from the streamflow and chemistry data at the sub-catchments 
(Figure 1) within the domain used in Carroll et al. (2018). The nitrogen export was computed in the same manner as Newcomer et al. (2021).
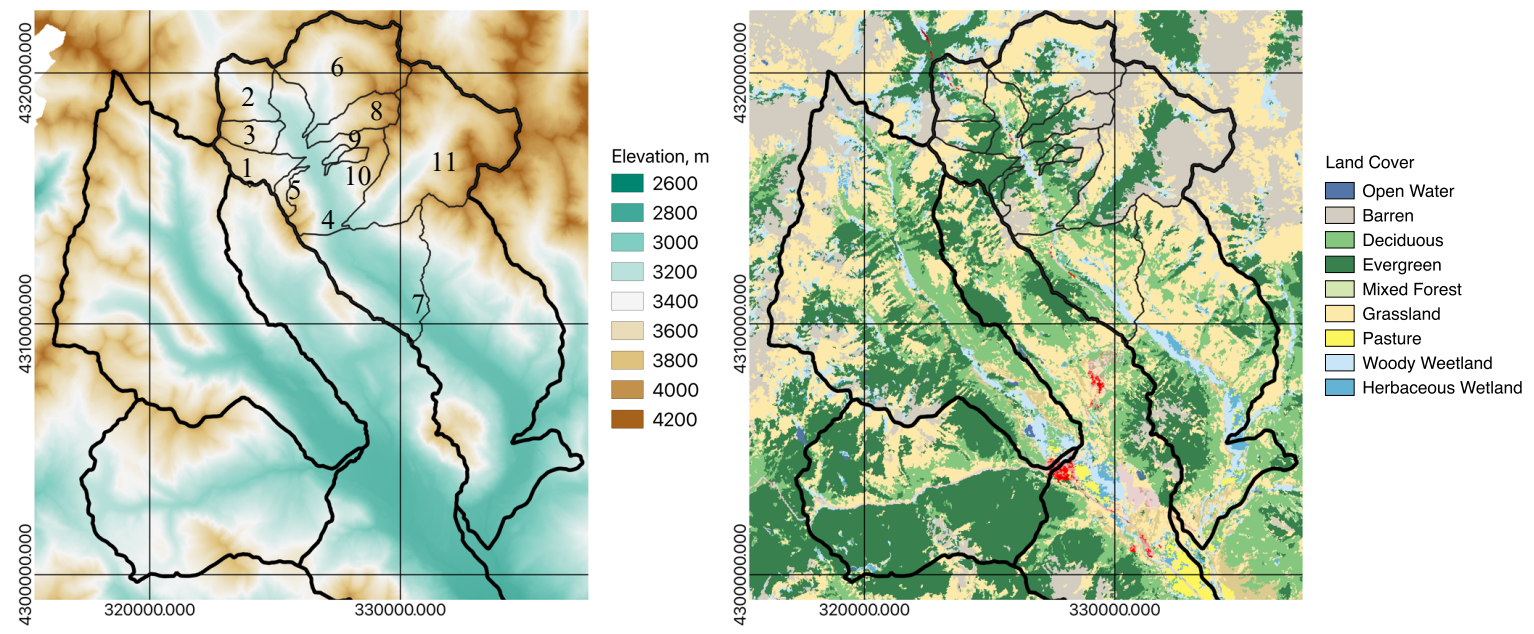

Figure 1. Study domain with (a) elevation and (b) land cover map (USGS NLCD 2011). The black lines are the boundaries of the four watersheds (from right to left: East River, Washington Gulch, Slate River and Coal Creek), and the thin black boundaries are sub-catchments of the East River watershed from Carroll et al. (2018): (1) Rock, (2) East Above Quigley (EAQ), (3) Quigley, (4) East Below Copper (EBC), (5) Gothic, (6) Rustlers, (7) Pumphouse, (8) Bradley, (9) Marmot, (10) Avery, and (11) Copper. In (b), the red region is the urban area.

\section{Methodology}

\subsection{Watershed and Hillslope Characteristics}

We followed Wainwright et al. (2020) to compute pixel-by-pixel topographic metrics based on the LiDAR Digital Elevation Model (DEM), including slope, Topographic Wetness Index (TWI), and annual net potential solar radiation. We selected metrics based on the previous studies that reported their relevance to soil moisture, soil thickness, water quality and others (Mohanty et al., 2000; Gillin et al., 2015; Lintern et al., 2018). In parallel, we delineated each hillslope based on the DEM, following Noel et al. (2014) and using Topotoolbox (Schwanghart, 2014). We set the threshold of flow accumulation to match the stream observations at major tributaries of the East River (Carroll et al., 2018). Although the hillslope is based on surficial water routing, we assume that the DEM captures near-surface hydrological connectivity as documented by Jensco et al. (2009). 
We then defined the characteristics of each hillslope, based on the spatial data layers (Figure S1). We computed the average values of the DEM topographic metrics, AEM-based bedrock resistivity, NEON products, and peak SWE in each hillslope. In addition, we computed the relief of each hillslope, which was the difference between the minimum and maximum elevation.

150 For the categorical variables such as land-cover types and geology, we computed the percent coverage of each plant type and surface geology in each hillslope. These 15 hillslope features are defined for each hillslope (Table S1).

\subsection{Cluster-Based Approach to identify Watershed Zones}

Based on the hillslope features, we first evaluated the correlations among multivariate parameters in above/belowground properties. Although such multivariate co-variability has been analyzed using principal component analysis (Devadoss et al.,

155 2020), we used scatter plots and correlation coefficients in this study because of nonlinearity. We then applied three commonly used unsupervised clustering methods: K-means (KM), hierarchical clustering (HC), and Gaussian mixture models (GMM; Hastie et al., 2001; Kassambara, 2017). We scaled each feature by the mean and standard deviation, and defined the dissimilarity between two data points based on the Euclidean distance. The characteristics of each method are described in Texts S2. Multiple methods are often evaluated based on true classes or labeled datasets (Rodriguez et al., 2019), which are not available here. We used a silhouette score, which represented how similar a given data point was to its own cluster compared to other clusters. For GMM, we used the Bayesian Information Criterion (BIC) for selecting the number of clusters to maximize BIC.

After the clusters are defined, we transfer the clusters - the group of hillslopes that have similar features - to the spatial map

165 as zones. We identify the common zones across the three methods as well as the zones that differ. We then evaluate the distribution of hillslope features and functions in each zone using box plots to define the characteristics of each zone. The foresummer drought sensitivity (Wainwright et al., 2020) is a watershed function available throughout the domain that allows us to quantify the hillslope-average values in the same manner as other spatial data layers. In addition, we computed the spatial coverage of each zone in each subcatchment, and compared them to the ratio between the annual nitrogen export and total discharge, which is considered as a key metric of how watersheds retain and lose nutrients (Newcomer et al., 2021).

\section{Results}

\subsection{Watershed Zonation}

Figure 2 shows that the above- and belowground hillslope features are significantly correlated with each other. In particular,

175 elevation is correlated with all other features except for net annual potential radiation. The hillslopes at higher elevation have steeper slopes and lower TWI, higher bedrock resistivity and higher peak SWE. There are some nonlinearities: TWI increases beyond the linear function at lower elevations. The relationship between peak NDVI and elevation is quadratic, having peaks 
https://doi.org/10.5194/hess-2021-228

Preprint. Discussion started: 10 May 2021

(c) Author(s) 2021. CC BY 4.0 License.

in mid-elevation (corresponding to around $3300 \mathrm{~m}$ ). The net annual potential radiation is weakly correlated with slope, TWI, and peak SWE. The correlation coefficients among the hillslope-averaged features are significantly higher than the ones of pixel-by-pixel ones (Figure S2).

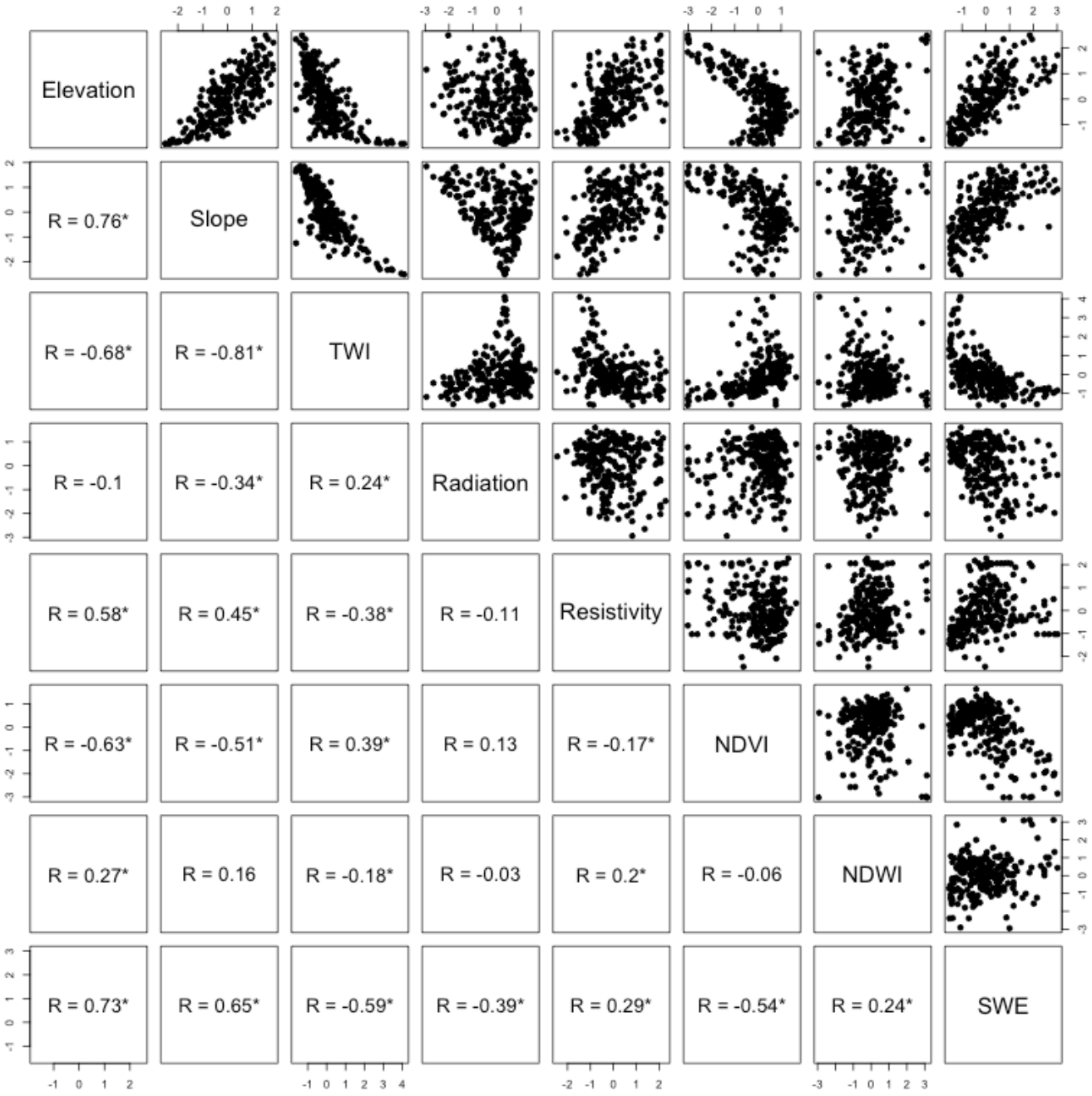

Figure 2. Correlation and scatter plots (Pearson's correlation coefficients) among selected hillslope features (Table S1). The * sign represents p-values $<\mathbf{0 . 0 1}$.

185 The clustering results are then mapped spatially as the watershed zones (Figure 3). The number of clusters is seven, since GMM showed the highest silhouette score at seven clusters (Figure S3a), and BIC is also highest at seven clusters (above five; Figure S3b). The zones are similar among the three methods, although there are minor differences. Zones 1-6 are common zones across the three methods. Zone 7 appears in GMM (Figure 3a), but is categorized as Zone 1 by the other methods. Zone 
https://doi.org/10.5194/hess-2021-228

Preprint. Discussion started: 10 May 2021

(c) Author(s) 2021. CC BY 4.0 License.

8 appears only in KM (Figure 3b); Zone 8 is mostly a part of Zone 3 in the other methods, although some Zone 8 hillslopes are represented as Zone 2 in GMM. Zone 9 appears in HC (Figure 3c), but is a part of Zone 3 in KM and HC. The frequency maps (Figure S4) show that some hillslopes are consistently categorized in the same zones among three methods.

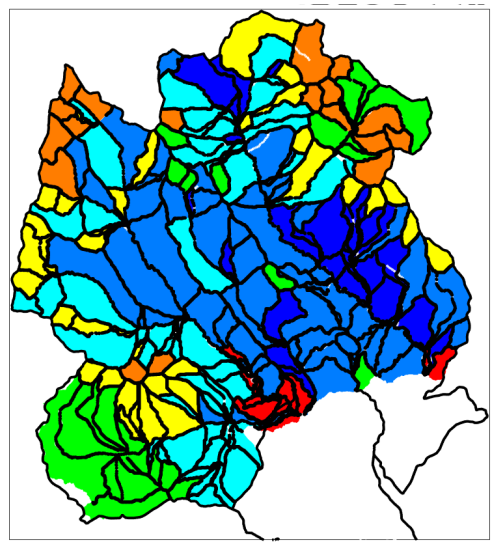

(a)

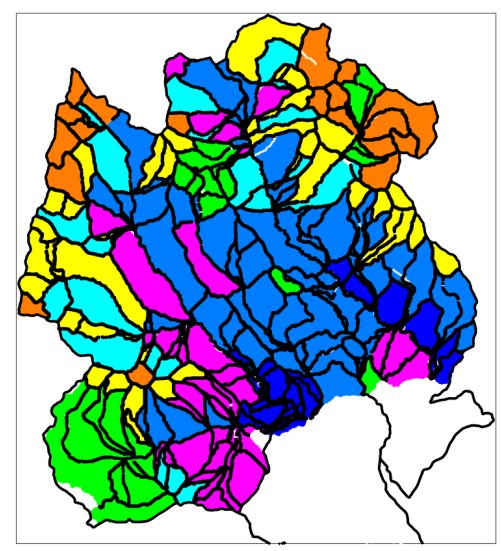

(b)

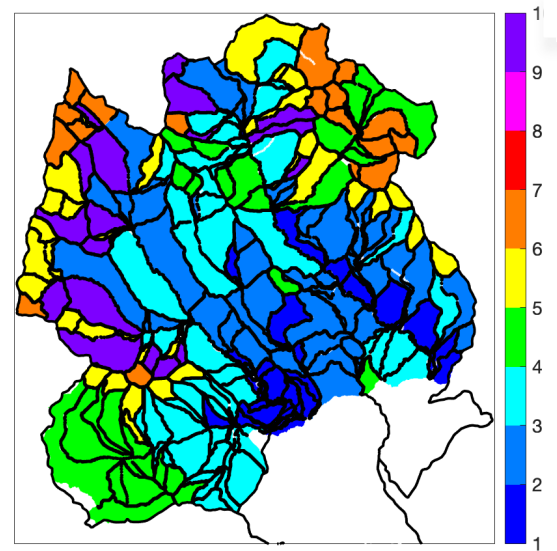

(c)

Figure 3. Hillslope zonation based on (a) Gaussian mixture model (GMM), (b) K-means (KM), and (c) hierarchical clustering (HC).

Each zone, colored according to the cluster index from 1 to 9, has a characteristic suite of above and below ground properties. There are 6 common zones among the three methods, and 3 additional zones (Zone 7 - 9) that are different. The black lines are the hillslope boundaries.

Box plots shows the characteristics of each identified zone (Figures 4 and 5). Although each map has seven zones, we use nine zones that are found across the three clustering methods based on the frequency map and take the average (Figure S4). Elevation (Figure 4a) increases from Zone 1 to 6, while Zone 7 is located at the lowest elevations. The elevation of Zone 8 is between that of Zone 2 and Zone 3, while Zone 9 is similar to 4. Slope (Figure 4b) shows a similar progression to elevation, which is consistent with the correlation plot (Figure 2). Relief (Figure 4c) also has a similar order to the elevation, except that Zones 5 to 6 are similar, because the higher elevation hillslopes are smaller with lower relief, even though the slope is high.

205 TWI (Figure 4d) has an opposite trend to elevation, consistent with the correlation plot (Figure 2). In terms of net potential radiation (Figure 4e), the grassland-dominated hillslopes (Zones 1,2,5) tend to be higher, while the conifer-dominated hillslopes (Zones 3, 4, 8, 9) are lower except for Zone 4 being around the average. The bedrock resistivity (Figure 4f) is higher at the higher elevation zones (Zones 4, 5, 6) or intrusive-rock -dominated zones (Zones 4 and 6). NDVI (Figure 4g) is higher in the forest-dominated zones (Zone 2, 3, 4, 8). Zone 6 has significantly lower NDVI, since it is predominantly in the barren region. NDWI (Figure 4h) is lower in the low elevation zones (Zones 1). Peak SWE (Figure 4i) is also associated with the elevation; it is the highest in Zone 6, which has the highest elevation, and the lower net potential radiation. 
https://doi.org/10.5194/hess-2021-228

Preprint. Discussion started: 10 May 2021

(c) Author(s) 2021. CC BY 4.0 License.

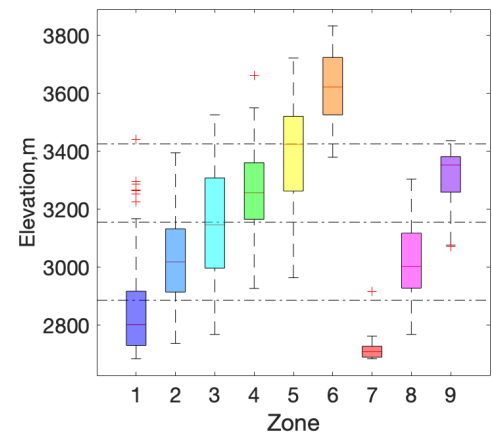

(a)

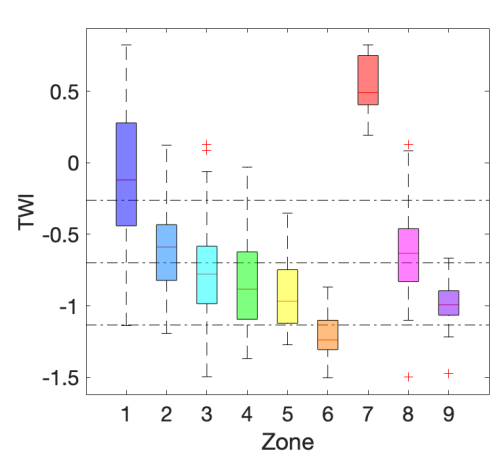

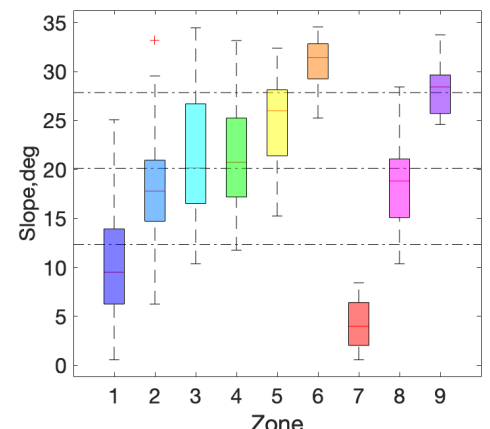

(b)

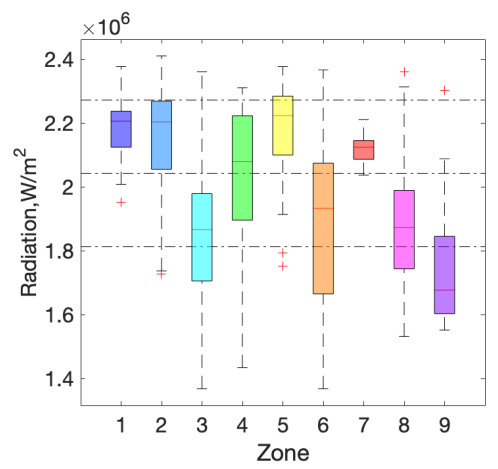

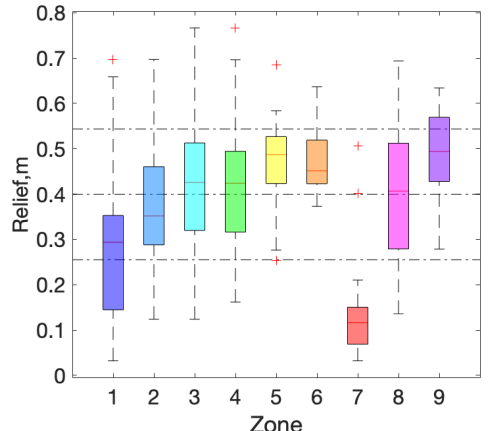

(c)

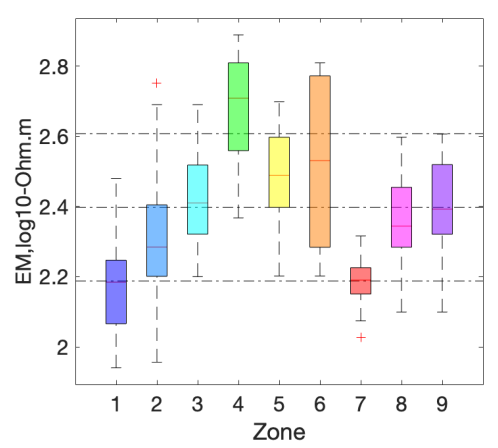

215

(d)

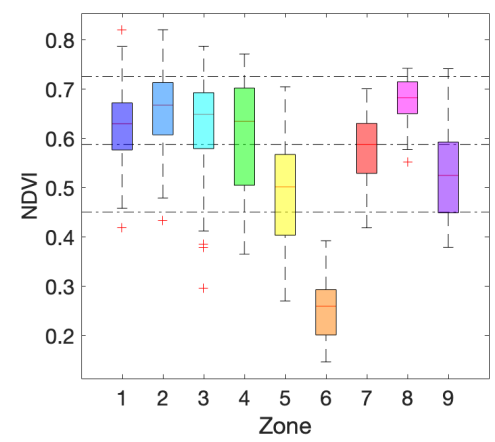

(g) (e)

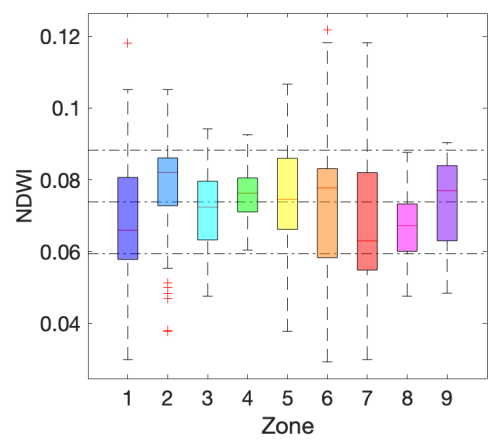

(h) (f)

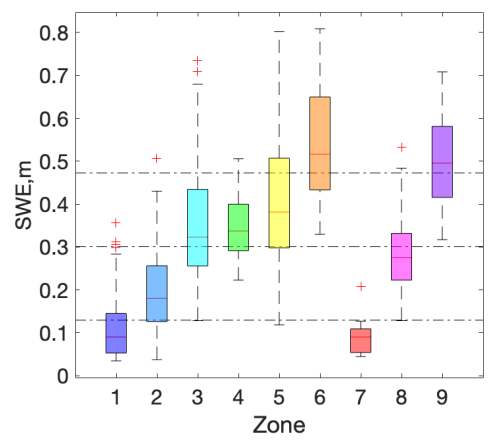

(i)

Figure 4. Boxplots of hillslope pattern features: (a) elevation, (b) slope, (c) relief, (d) TWI, (e) annual net potential radiation, (f) bedrock electrical resistivity (top $20 \mathrm{~m}$ ), (g) peak NDVI in 2018, (h) NDWI (at peak NDVI) in 2018, and (i) peak SWE in 2018. The horizontal lines are the overall mean and plus/minus one standard deviation.

With respect to geology (Figure 5a-c); shale coverage (Figure 5a) decreases in the higher-elevation zones that see a concomitant increase in intrusive rocks and hydrothermally altered sandstones (Zones 4, 5, 6, 8), whereas non-altered 
https://doi.org/10.5194/hess-2021-228

Preprint. Discussion started: 10 May 2021

(c) Author(s) 2021. CC BY 4.0 License.

225 sandstone regions (Figure 5b) are dominant in mid-elevation hillslopes (Zone 3 and 5). Among the conifer-dominated areas (Zones 3, 4, 8, 9), most (Zones 3, 8 and 9) are associated with shale and sandstone, while Zones 4 are associated with intrusive rock. In terms of land-cover types (Figure 5d-g), the barren area coverage (Figure 5d) increases with elevation from Zone 1 to 6. The grassland region (Figure 5e) exists across all zones, but it is particularly high in the low-elevation zones (Zones 1 and 2) and the higher-elevation south-facing zone (Zone 5). The coverage of deciduous vegetation (Figure 5f) is higher at lower 230 elevation (i.e., Zones 1, 2, 7); Zone 2 in particular has high aspen coverage. Finally, the evergreen forest regions (Figure 5g) appear in Zones 3, 4, 8, and 9, which are associated with the mid-range elevation, higher slope, and lower net potential radiation. Zone 4 has a higher coverage of intrusive rock, while Zone 3, 8 and 9 are in the shale-sandstone regions. The difference among Zone 3, 8 and 9 are separated such that Zone 9 has particularly high elevation and SWE, and Zone 8 has particularly high NDVI. The characteristics of each zone is summarized in Table 1.

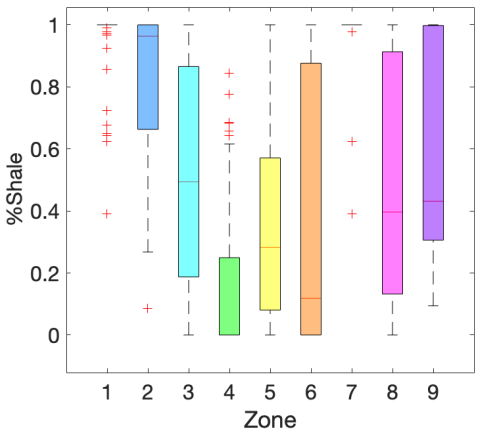

(a)

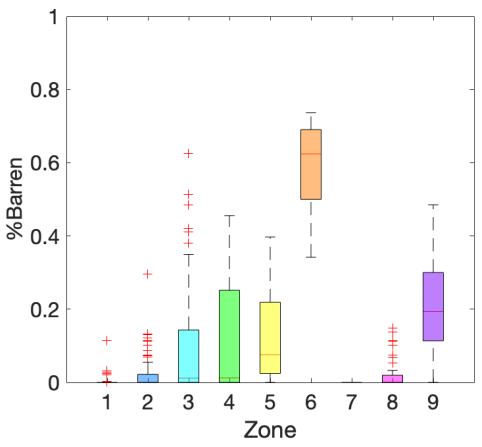

(d)

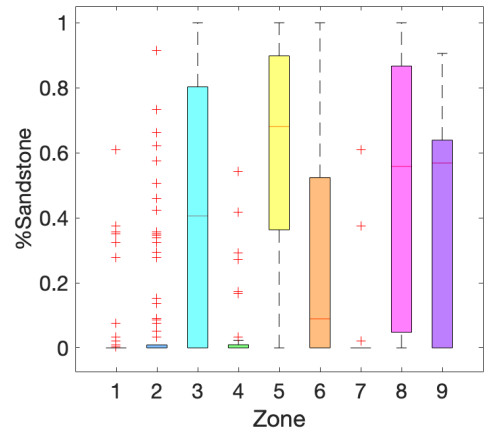

(b)

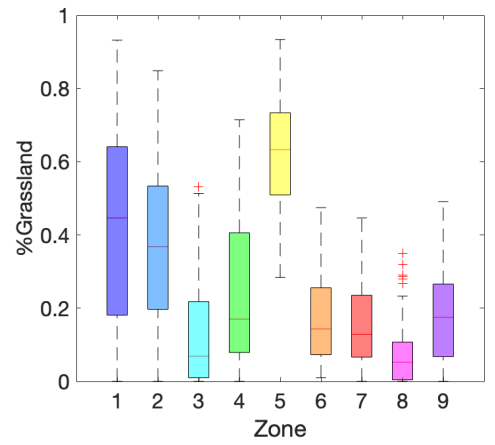

(e)

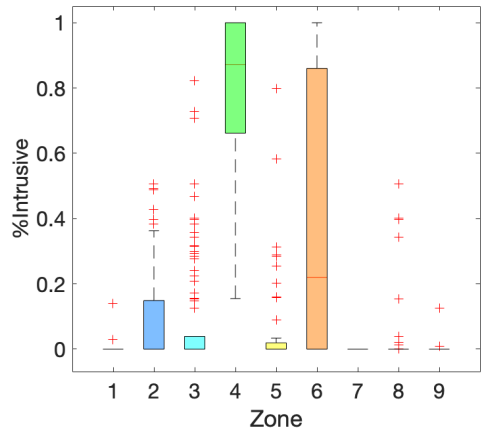

(c)

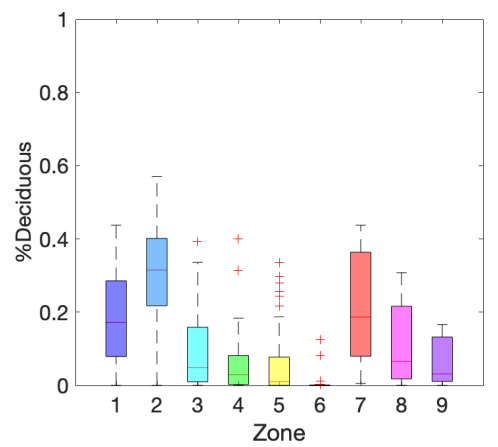

(f) 


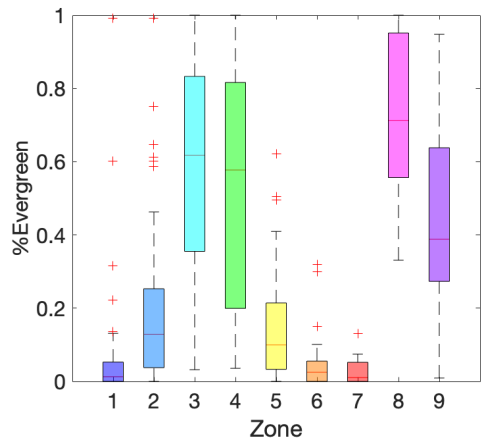

(g)

Figure 5. Boxplots of hillslope pattern features with respect to geology and land-cover types: the percent coverage of (a) shale, (b) sandstone, (c) igneous (intrusive) rock, (d) barren, (e) grassland, (f) deciduous forest and (g) evergreen forest.

245 Table 1. Summary of the features in each zone based on Figure 5 and 6.

\begin{tabular}{|l|l|l|l|l|l|l|l|l|l|}
\hline Zone & Elevation & Slope & TWI & Resistivity & Radiation & Peak NDVI & Peak SWE & Plant types \\
\hline 1 & Low & Low & High & Low & Mid-High & Mid & Low & Grassland \\
\hline 2 & Low-Mid & Low-Mid & Mid-High & Low-Mid & Mid-High & Mid-High & Low-Mid & Grassland-Deciduous & Shale \\
\hline 3 & Mid & Mid & Mid-High & Mid & Low & Mid-High & Mid & Evergreen \\
\hline 4 & Mid & Mid-High & Low-Mid & High & Mid & Mid-High & Mid-High & Evergreen \\
\hline 5 & Mid-High & Mid-High & Low-Mid & Mid-High & Mid-High & Low-Mid & Mid-High & Grassland \\
\hline 6 & High & High & Low & High & Mid-Low & Low & High & Barren & Shale-Sandstone \\
\hline 7 & Very low & Low & Very high & Low & Mid-High & Mid & Low & Grassland-Deciduous & Shale \\
\hline 8 & Mid & Mid & Mid & Low-Mid & Mid-Low & Mid-High & Mid & Evergreen \\
\hline 9 & Mid-High & High & Low & Low-Mid & Low & Low-Mid & Mid-High & Evergreen \\
\hline
\end{tabular}

\subsection{Watershed Functions}

Foresummer drought sensitivity (Figure 6a) has an opposite trend to elevation (Figure 4a), with higher sensitivity in lowerelevation zones (Zone 1, 2, 7), and the lowest in Zone 6. Zone 5 - high-elevation south-facing grassland-dominated hillslopes 250 - has higher sensitivity than the zones that are in a similar range. The conifer-dominated zones (Zones $3,4,8$, and 9) have lower-than-average sensitivity. Tukey's pairwise comparison metrics suggest that the differences are significant except in the case of conifer-dominated Zones (3, 4, 8, and 9).

We found that the magnitude of annual nitrogen exports scaled log-linearly with discharge, albeit with bifurcation among some 255 of the smaller catchments (Figure 6c). The Rock and Gothic subcatchments, which are predominantly within coniferdominated Zone 3 (Figure b). By contrast, Zone 2 dominated subcatchments (Marmot, Avery) have a larger nitrogen export 
https://doi.org/10.5194/hess-2021-228

Preprint. Discussion started: 10 May 2021

(c) Author(s) 2021. CC BY 4.0 License.

than would be expected from the simple scaling relationship. In addition, we computed the correlation between the $\mathrm{N}$ export and $\%$ coverage of each zonation, which are $0.54(\mathrm{p}$-value $=0.01)$ for Zone 2 , and $-0.67(\mathrm{p}$-value $=0.02)$ for Zone 3 (Figure $6 \mathrm{~d}$ and e).

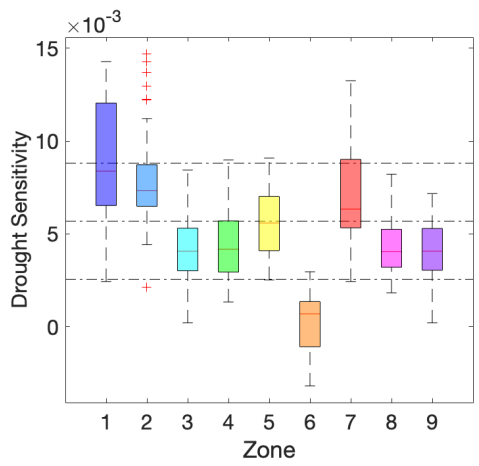

(a)

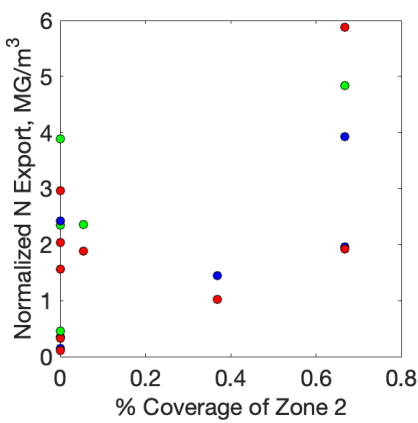

(d)

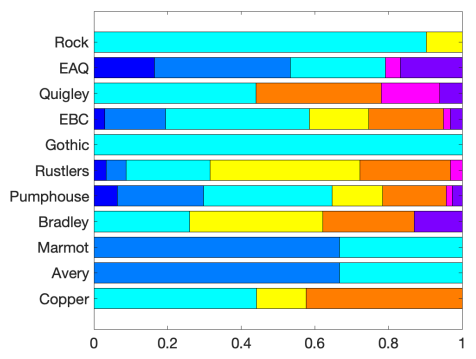

(b)

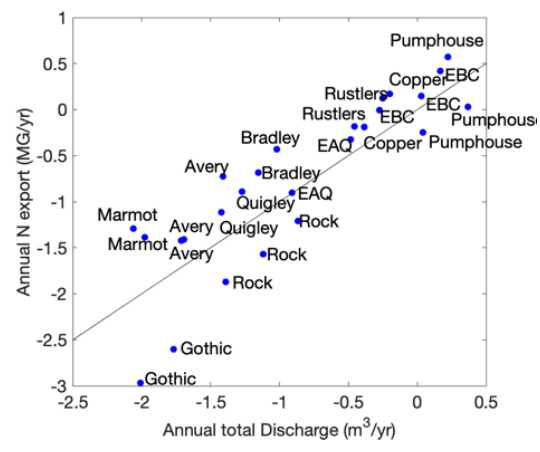

(c)

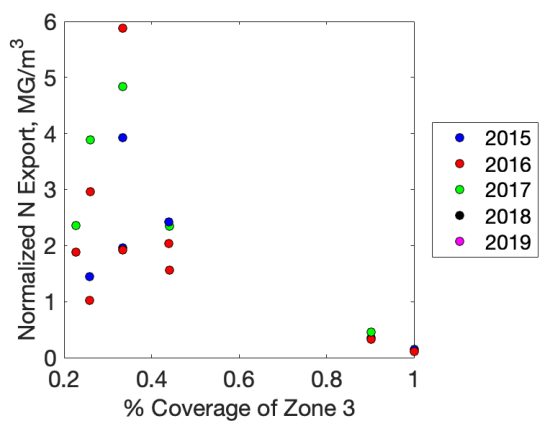

(e)

265 Figure 6. (a) Boxplot of the foresummer drought sensitivity as a function of zones, (b) zonation coverage of each subcatchment, (c) annual discharge vs $\mathrm{N}$ export in 2015, 2016 and 2017, and (d, e) normalized $\mathrm{N}$ export ( $\mathrm{N}$ export divided by annual discharge) as a function of the percent coverage of (d) Zone 2 and (e) Zone 3, respectively. In (b), the color code is the same as Figure 3 - 5.

\section{Discussion}

We first identified the co-variability between topographic metrics, elevation, bedrock resistivity, and plant signatures at the watershed scale. In particular, the near-surface bedrock electrical resistivity is significantly correlated to slope and elevation. The detailed analysis of AEM by Uhlemann et al. (submitted) has found that, (1) bedrock resistivity is primarily controlled by bedrock type, and (2) within the shale and sandstone, the bedrock resistivity is affected by the extent of hydrothermal alteration. The relationship between topography, elevation, and bedrock strength has been documented extensively (e.g., Selby, 1987; Clarke and Burbank, 2010). Montgomery (2001) showed that, in low-precipitation and low soil production environments, such 
as the East River, the erosion rate is dependent on rock strength and slope steepness, whereby erosion-resistant rock (i.e., hydrothermally-altered sandstones and shales and/or igneous rocks) are on steeper slopes than more erodible rocks. Erosionresistant rocks also remain at higher elevations, while erodible rock erodes away. This work provides information on how surface topographic features are linked to bedrock variability and could be potentially used to inform bedrock variability, which is considered as one of the largest uncertainties in watershed science (Fan et al., 2019).

Our results show that plant signatures and peak SWE are primarily correlated with elevation. The quadratic dependency of NDVI and aboveground biomass on elevation is consistent with previous studies (e.g., Wainwright et al., 2020); productivity and biomass increases with elevation up to 3300-3500 m because plants have more access to snow-derived water at higher elevation. Above $3500 \mathrm{~m}$, plant productivity is limited by temperature. Net annual potential radiation is not correlated with elevation, but associated with conifer coverage and peak SWE. The conifer forest and high vegetative biomass are associated with north-facing slopes due to higher water availability, which is consistent with previous syntheses studies (e.g., Pelletier et al. 2018). The spatial variability of peak SWE is also consistent with previous studies being associated with elevation and radiation (Anderson et al., 2016). In addition, the conifer-dominated zones are associated with high-resistivity bedrock, while aspen forests are located within the less resistive bedrock. This is consistent with past studies that conifer trees grow in the shallow bedrock regions, while aspen require the establishment of deeper root systems (e.g., Burke and Kasahara, 2011). Although there have been studies that have reported the co-variability of plants, topographic metrics, and aspect-controlled bedrock weathering (e.g., Pelletier et al, 2018), our analysis suggested an additional control of geological variability.

295 We found that hillslope-averaged metrics improve the correlations significantly, compared with pixel-by-pixel correlations. In natural systems, the degree of heterogeneity increases as the domain of interest increases (e.g., Neumann et al., 2003). The key controls change depending on the scale; while microtopography is a major control on snow (both in accumulation and melting) and soil moisture within hillslopes (Falco et al., 2019; Devadoss et al., 2020), elevation and aspect become major controls at a large scale (Pelletier et al., 2018; Fan et al., 2019). Our analysis showed that when we evaluated the watershed-scale heterogeneity, hillslopes would be an appropriate unit for capturing the key controls on co-varied above/belowground properties and watershed functions. This is consistent with Wood et al. (2011), concluding that the order of $100 \mathrm{~m}$ is a sufficient resolution for representing hydrological fluxes.

The co-variability between aboveground and belowground properties suggests that we may reduce the complexity or multidimensionality of watershed heterogeneity. We identified zones that capture co-varied properties through unsupervised clustering, which is compressing the multidimensional parameter space into one-dimensional classes. In the East River watershed, the zones are primarily dictated by elevation, while aspect or radiation poses orthogonal controls to the elevation. Geology and bedrock are also correlated with elevation, such that hillslopes dominated by crystalline rocks and hydrothermally-altered shales and sandstones are primarily found at higher elevations. The plant types are associated with 
both elevation and radiation, such that the dominant type changes from grassland, aspen, conifer, and grassland to barren from low to high elevations, and conifers are dominant in the north-facing hillslopes.

We compared three commonly used clustering methods: hierarchical clustering, k-means, and Gaussian mixture models. Such methodological or conceptual model uncertainties are important to characterize, since they are often larger than parameter uncertainty (Neumann et al., 2003; Ye et al., 2010). Based on the frequency map, we can also identify the hillslopes that are consistently categorized in each zone as most representative hillslopes in that zone. In addition, our results show that different methods yield fairly similar zones provided the distance metrics are the same. Differences could be explained as the further division of an identified zone, such that one method divided a zone into two, due to a particular metric. For example, the lower elevation south facing hillslopes were divided into Zone 1 and 7, due to high TWI in Zone 7, which was also associated with low drought sensitivity.

The zones are evaluated with the metrics associated with key watershed functions, including foresummer drought sensitivity of plant productivity and river nitrogen export from subcatchments. Drought sensitivity is mainly affected by the dominant plant species in the hillslopes, which is consistent with Wainwright et al. (2020). The conifer-dominated hillslopes have lower sensitivity to the droughts, since they are located mostly in north-facing hillslopes and conifer trees have deeper roots. However, there is a difference in two grassland-dominated zones: Zone 5 and Zone 1, with the high elevation grassland less sensitive to droughts, possibly owing to increased water availability in higher elevation. Nitrogen export is known to be controlled by multiple factors, such as plant retention, soil cover (Sickman et al., 2002) and geology (Wan et al., 2019). Our analysis showed that the conifer-dominated zone (Zone 3) is associated with low nitrogen export, while Zone 2, which has the highest fraction of aspen forests, is associated with higher $\mathrm{N}$ export. Conifer forests have previously been observed to have high nitrogen retention (Abrahamsen and Stuanes, 1998, Sollins et al., 1981), particularly through ectomycorrhizal uptake (Höberg et al., 2011). By contrast, deciduous aspen forests produce annual leaf litters, with a low C:N content, releasing nitrogen back to the soil (e.g., DeByle et al., 1985; Köchy and Wilson, 1997, Buck \& St. Clair, 2012). In addition, Wan et al. (2019) found that shale was a significant geogenic source of nitrogen, based on the intensive observation sites located in Zone

3352 of this watershed, which is consistent with the global data synthesis (Houlten et al., 2018). We found that the coniferdominant hillslopes, including those in Zone 3, were in sandstone or igneous rock regions, or in less resistive shale (which is assumed to have a lower fracture density). These factors may be combined to reduce the nitrogen delivery to the river in the conifer-dominated hillslopes, and thus the lower observed river nitrogen exports from that sub-watershed.

340 Our approach provides an objective way to classify different hillslopes by including the variability associated with different clustering methods. Although it is similar to catchment clustering and classification of past studies (e.g., Krause et al. 2014), those studies defined the classes of watersheds based on streamflow signatures, which were sparse; particularly in headwater catchments. The expansion of spatial data layers from various remote-sensing data layers provides alternative opportunities to 
apply clustering to such spatial features. In addition, although our approach is similar the Hydrological Response Unit approach

(Flugel, 1997) or hillslope clustering done by Chaney et al. (2018), their main purpose was to parameterize hydrological models. Our analysis confirmed the significance of zonation using the key watershed properties and functions based on observational datasets. Since hillslope-scale studies and experiments are an integral part of watershed science and critical zone science (Hinckley et al., 2014; Tokunaga et al. 2019; Wan et al. 2019), our zonation approach can guide the placement of experimental plots more effectively, as well as improve model parameterization in large-scale hydrological models (Chainy et al., 2019) by honoring distinct boundaries and water/element export contributions.

\section{Acknowledgements}

This material is based upon work supported as part of the Watershed Function Scientific Focus Area funded by the U.S. Department of Energy, Office of Science, Office of Biological and Environmental Research under Award Number DE-AC0205CH11231. This work was also supported in part by the U.S. Department of Energy, Office of Science, Office of Workforce

Development for Teachers and Scientists (WDTS) under the Science Undergraduate Laboratory Internship (SULI) program and Workforce Development and Education at Lawrence Berkeley National Laboratory. The airborne EM data were acquired with funding from the USGS Mineral Resources Program. All data files associated with calculating nitrogen fluxes (gap-filled nitrogen concentrations and gap-filled discharge) are freely available on ESS-DIVE (https://ess-dive.lbl.gov/) for free-public access.

\section{References}

Abrahamsen, G., \& Stuanes, A. O. (1998). Retention and leaching of N in Norwegian coniferous forests. Nutrient cycling in agroecosystems, 52(2-3), 171-178.

Anderson, B. T., McNamara, J. P., Marshall, H. P., \& Flores, A. N. (2014). Insights into the physical processes controlling correlations between snow distribution and terrain properties, Water Resources Research, 50(6), 4545-4563.

Asner, G. P., Martin, R. E., Anderson, C. B., \& Knapp, D. E. (2015). Quantifying forest canopy traits: Imaging spectroscopy versus field survey. Remote Sensing of Environment. doi:10.1016/j.rse.2014.11.011

370 Aytaç, E. (2020). Unsupervised learning approach in defining the similarity of catchments: Hydrological response unit based k-means clustering, a demonstration on Western Black Sea Region of Turkey. International Soil and Water Conservation Research, 8(3), 321-331. 
https://doi.org/10.5194/hess-2021-228

Hydrology and

Preprint. Discussion started: 10 May 2021

(c) Author(s) 2021. CC BY 4.0 License.

Ball, L. B., Davis, T. A., Minsley, B. J., Gillespie, J. M., \& Landon, M. K. (2020), Probabilistic categorical groundwater salinity mapping from airborne electromagnetic data adjacent to California's Lost Hills and Belridge oil fields. Water Resources Research, e2019WR026273.

Barfod, A. A., Møller, I., Christiansen, A. V., Høyer, A. S., Hoffimann, J., Straubhaar, J., \& Caers, J. (2018). Hydrostratigraphic modeling using multiple-point statistics and airborne transient electromagnetic methods. Hydrology \& 380 Earth System Sciences, 22(6).

Brantley, S. L., McDowell, W. H., Dietrich, W. E., White, T. S., Kumar, P., Anderson, S. P., ... \& Gaillardet, J. (2017). Designing a network of critical zone observatories to explore the living skin of the terrestrial Earth. Earth Surface Dynamics, $5(4), 841-860$.

Buck, J. R., \& Clair, S. B. S. (2012). Aspen increase soil moisture, nutrients, organic matter and respiration in Rocky Mountain forest communities. PLoS One, 7(12), e52369.

Burke, A. R., \& Kasahara, T. (2011). Subsurface lateral flow generation in aspen and conifer-dominated hillslopes of a first order catchment in northern Utah. Hydrological Processes, 25(9), 1407-1417.

Burt, T. P., \& Pinay, G. (2005). Linking hydrology and biogeochemistry in complex landscapes. Progress in Physical geography, 29(3), 297-316.

395 Carroll, R. W., Bearup, L. A., Brown, W., Dong, W., Bill, M., Williams, K. H. (2018). Factors Controlling Seasonal Groundwater and Solute Flux from Snow-Dominated Basins, Hydrological Processes, 1-16, 10.1002/hyp.12151

Chadwick, K. D., Brodrick, P. G., Grant, K., Goulden, T., Henderson, A., Falco, N., ... \& Brodie, E. L. (2020). Integrating airborne remote sensing and field campaigns for ecology and Earth system science. Methods in Ecology and Evolution.

Chaney, N. W., Van Huijgevoort, M. H. J., Shevliakova, E., Malyshev, S., Milly, P. C. D., Gauthier, P. P. G., and Sulman, B. N.: Harnessing big data to rethink land heterogeneity in Earth system models, Hydrol. Earth Syst. Sci., 22, 3311-3330, https://doi.org/10.5194/hess-22-3311-2018

405 Clarke, B. A., \& Burbank, D. W. (2010). Bedrock fracturing, threshold hillslopes, and limits to the magnitude of bedrock landslides. Earth and Planetary Science Letters, 297(3-4), 577-586. 
https://doi.org/10.5194/hess-2021-228

Colombo, R., Meroni, M., Marchesi, A., Busetto, L., Rossini, M., Giardino, C., \& Panigada, C. (2008). Estimation of leaf and canopy water content in poplar plantations by means of hyperspectral indices and inverse modeling. Remote sensing of environment, 112(4), 1820-1834.

DeByle, N. V. (1985). Water and watershed. In: DeByle, Norbert V.; Winokur, Robert P., editors. Aspen: Ecology and management in the western United States. USDA Forest Service General Technical Report RM-119. Rocky Mountain Forest and Range Experiment Station, Fort Collins, Colo. p. 153-160, 119.

Devadoss, J., Falco, N., Dafflon, B., Wu, Y., Franklin, M., Hermes, A., ... \& Wainwright, H. (2020). Remote Sensing-Informed Zonation for Understanding Snow, Plant and Soil Moisture Dynamics within a Mountain Ecosystem. Remote Sensing, 12(17), 2733.

Duncan, J. M., Groffman, P. M., \& Band, L. E. (2013). Towards closing the watershed nitrogen budget: Spatial and temporal scaling of denitrification. Journal of Geophysical Research: Biogeosciences, 118(3), 1105-1119.

Engstrom, R., Hope, A., Kwon, H., Stow, D., \& Zamolodchikov, D. (2005). Spatial distribution of near surface soil moisture and its relationship to microtopography in the Alaskan Arctic coastal plain. Hydrology Research, 36(3), 219-234.

Falco, N., Wainwright, H., Dafflon, B., Léger, E., Peterson, J., Stelzer, H., ... \& Hubbard, S. S. (2019). Remote sensing and geophysical characterization of a floodplain-hillslope system in the East River watershed, Colorado. Watershed Functionality Scientific Focus Area.

430 Fan, Y., Clark, M., Lawrence, D. M., Swenson, S., Band, L. E., Brantley, S. L., et al. ( 2019). Hillslope hydrology in global change research and Earth system modeling. Water Resources Research, 55, 1737- 1772. https://doi.org/10.1029/2018WR023903.

Feilhauer, H., Asner, G. P., \& Martin, R. E. (2015). Multi-method ensemble selection of spectral bands related to leaf biochemistry. Remote Sensing of Environment. doi:10.1016/j.rse.2015.03.033.

Flugel, W. A. (1997). Combining GIS with regional hydrological modelling usinghydrological response units (HRUs): An application from Germany.Mathematicsand Computers in Simulation, 43(3e6), 297e304.https://doi.org/10.1016/S03784754(97)00013-X. 
https://doi.org/10.5194/hess-2021-228

Hydrology and

Preprint. Discussion started: 10 May 2021

(c) Author(s) 2021. CC BY 4.0 License.

Gaskill, D.L., F.E. Mutschler, J.H. Kramer, J.A. Thomas, and S.G. Zahony. 1991. USGS Geologic map of the Gothic Quadrangle, Gunnison County, Colorado.

Gillin, C. P., Bailey, S. W., McGuire, K. J., \& Gannon, J. P. (2015). Mapping of hydropedologic spatial patterns in a steep headwater catchment. Soil Science Society of America Journal, 79(2), 440. https://doi.org/10.2136/sssaj2014.05.0189.

Green, G.N., 1992, The Digital Geologic Map of Colorado in ARC/INFO Format: U.S. Geological Survey Open-File Report 92-0507, 9 p.; http://pubs.usgs.gov/of/1992/ofr-92-0507/ .

450 Groffman, P. M., Butterbach-Bahl, K., Fulweiler, R. W., Gold, A. J., Morse, J. L., Stander, E. K., ... \& Vidon, P. (2009). Challenges to incorporating spatially and temporally explicit phenomena (hotspots and hot moments) in denitrification models. Biogeochemistry, 93(1), 49-77.

Hastie T., Tibshirani, R., and Friedman, J. H. (2001), The elements of statistical learning: data mining, inference, and prediction, Springer, New York, USA.

Hermes, A. L., Wainwright, H. M., Wigmore, O. H., Falco, N., Molotch, N., \& Hinckley, E. L. S. (2020). From patch to catchment: A statistical framework to identify and map soil moisture patterns across complex alpine terrain. Frontiers in Water, 2,48 .

Hinckley, E.-L. S., R. T. Barnes, S. P. Anderson, M. W. Williams, and S. M. Bernasconi (2014), Nitrogen retention and transport differ by hillslope aspect at the rain-snow transition of the Colorado Front Range, J. Geophys. Res. Biogeosci., 119, 1281-1296, doi:10.1002/ 2013JG002588.

465 Högberg, P., Johannisson, C., Yarwood, S., Callesen, I., Näsholm, T., Myrold, D. D., \& Högberg, M. N. (2011). Recovery of ectomycorrhiza after 'nitrogen saturation'of a conifer forest. New Phytologist, 189(2), 515-525.

Houlton, B. Z., Morford, S. L., \& Dahlgren, R. A. (2018). Convergent evidence for widespread rock nitrogen sources in Earth's surface environment. Science, 360(6384), 58-62.

Hubbard, S. S., Gangodagamage, C., Dafflon, B., Wainwright, H., Peterson, J., Gusmeroli, A., ... \& Tweedie, C. (2013). Quantifying and relating land-surface and subsurface variability in permafrost environments using LiDAR and surface geophysical datasets. Hydrogeology Journal, 21(1), 149-169. 
https://doi.org/10.5194/hess-2021-228

Hydrology and

Preprint. Discussion started: 10 May 2021

(c) Author(s) 2021. CC BY 4.0 License.

475 Hubbard, S. S., Williams, K. H., Agarwal, D., Banfield, J., Beller, H., Bouskill, N., ... \& Falco, N. (2018). The East River, Colorado, Watershed: A mountainous community testbed for improving predictive understanding of multiscale hydrologicalbiogeochemical dynamics. Vadose Zone Journal, 17(1), 1-25.

Hubbard, S. S., Varadharajan, C., Wu, Y., Wainwright, H., \& Dwivedi, D. (2020). Emerging technologies and radical 480 collaboration to advance predictive understanding of watershed hydrobiogeochemistry. Hydrological Processes, 34(15), 31753182 .

Jencso, K. G., McGlynn, B. L., Gooseff, M. N., Wondzell, S. M., Bencala, K. E., \& Marshall, L. A. (2009). Hydrologic connectivity between landscapes and streams: Transferring reach-and plot-scale understanding to the catchment scale. Water

485 Resources Research, 45(4).

Kassambara, A. (2017). Practical guide to cluster analysis in R: Unsupervised machine learning (Vol. 1). Sthda.

Krause, S., J. Freer, D. Hannah, N. Howden, T. Wagener, and F. Worrall (2014). Catchment similarity concepts for 490 understanding dynamic biogeochemical behavior of river basins, Hydrol Process, 28(3), 1554-1560, doi:10.1002/hyp.10093.

Köchy, M., \& Wilson, S. D. (1997). Litter decomposition and nitrogen dynamics in aspen forest and mixed-grass prairie. Ecology, 78(3), 732-739.

495 Kuentz, A., Arheimer, B., Hundecha, Y., \& Wagener, T. (2017). Understanding hydrologic variability across Europe through catchment classification. Hydrology and Earth System Sciences, 21(6), 2863-2879.

Li, L., Maher, K., Navarre-Sitchler, A., Druhan, J., Meile, C., Lawrence, C., ... \& Jin, L. (2017). Expanding the role of reactive transport models in critical zone processes. Earth-science reviews, 165, 280-301.

500

Lintern, Webb, Ryu, Liu, Waters, Leahy, Bende-Michl, and Western (2018), What Are the Key Catchment Characteristics Affecting Spatial Differences in Riverine Water Quality?, Water Resources Research, doi:10.1029/2017WR022172.

Madritch, M. D., Kingdon, C. C., Singh, A., Mock, K. E., Lindroth, R. L., \& Townsend, P. A. (2014). Imaging spectroscopy 505 links aspen genotype with below-ground processes at landscape scales. Philosophical Transactions of the Royal Society B: Biological Sciences, 369(1643), 20130194. 
https://doi.org/10.5194/hess-2021-228

Hydrology and

Preprint. Discussion started: 10 May 2021

(c) Author(s) 2021. CC BY 4.0 License.

Maxwell, R. M. and Kollet, S. J. (2008). Quantifying the effects of three-dimensional subsurface heterogeneity on Hortonian runoff processes using a coupled numerical, stochastic approach, Adv. Water Resour., 31, 807-817, https://doi.org/10.1016/j.advwatres.2008.01.020.

Minsley, B.J. and L.B. Ball (2018), Airborne geophysical characterization of geologic structure in a mountain headwater system, 7th International Workshop on Airborne Electromagnetics, Kolding, Denmark, 17-20 June.

515 McDonnell, J. J., \& Woods, R. (2004). On the need for catchment classification. Journal of Hydrology, 299, 2-3.

McDonnell et al. (2007). Moving beyond heterogeneity and process complexity: A new vision for watershed hydrology, Water Resources Research, 43(7), doi:10.1029/2006wr005467.

Mohanty, B. P., Famiglietti, J. S., \& Skaggs, T. H. (2000). Evolution of soil moisture spatial structure in a mixed vegetation pixel during the Southern Great Plains 1997 (SGP97) Hydrology Experiment. Water Resources Research, 36(12).

Montgomery, D. R. (2001). Slope distributions, threshold hillslopes, and steady-state topography. American Journal of science, 301(4-5), 432-454.

Neuman, S. P., \& Di Federico, V. (2003). Multifaceted nature of hydrogeologic scaling and its interpretation. Reviews of Geophysics, 41(3).

Neuman, S. P. (2003). Maximum likelihood Bayesian averaging of uncertain model predictions. Stochastic Environmental

Research and Risk Assessment, 17(5), 291-305.

Newcomer, M. E., Bouskill, N. J., Wainwright, H., Maavara, T., Arora, B., Siirila-Woodburn, E. R., ... \& Hubbard, S. S. (2021). Hysteresis patterns of watershed nitrogen retention and loss over the past 50 years in United States hydrological basins. Global Biogeochemical Cycles, e2020GB006777.

Noël, P., Rousseau, A. N., Paniconi, C., \& Nadeau, D. F. (2014). Algorithm for delineating and extracting hillslopes and hillslope width functions from gridded elevation data. Journal of Hydrologic Engineering, 19(2), 366-374.

Painter, T. H., Berisford, D. F., Boardman, J. W., Bormann, K. J., Deems, J. S., Gehrke, F., ... \& Mattmann, C. (2016). The 540 Airborne Snow Observatory: Fusion of scanning lidar, imaging spectrometer, and physically-based modeling for mapping snow water equivalent and snow albedo. Remote Sensing of Environment, 184, 139-152. 
Patton, N. R., Lohse, K. A., Godsey, S. E., Crosby, B. T., \& Seyfried, M. S. (2018). Predicting soil thickness on soil mantled hillslopes. Nature communications, 9(1), 1-10.

545 Peters-Lidard, C. D., Clark, M., Samaniego, L., Verhoest, N. E., Van Emmerik, T., Uijlenhoet, R., ... \& Woods, R. (2017). Scaling, similarity, and the fourth paradigm for hydrology. Hydrology and earth system sciences, 21(7), 3701.

de Pasquale, G., Linde, N., \& Greenwood, A. (2019). Joint probabilistic inversion of DC resistivity and seismic refraction data applied to bedrock/regolith interface delineation. Journal of Applied Geophysics, 170, 103839.

Pelletier, J. et al. (2018), Which way do you lean? Using slope aspect variations to understand Critical Zone processes and feedbacks, Earth Surface Processes and Landforms, 43(5), 1133-1154, doi:10.1002/esp.4306.

Peters-Lidard, C. D., Clark, M., Samaniego, L., Verhoest, N. E., Emmerik, T. V., Uijlenhoet, R., ... \& Woods, R. (2017).

Scaling, similarity, and the fourth paradigm for hydrology. Hydrology and earth system sciences, 21(7), 3701-3713.

Prancevic, J., and J. Kirchner (2019), Topographic Controls on the Extension and Retraction of Flowing Streams, Geophys Res Lett, 46(4), 2084-2092, doi:10.1029/2018g1081799.

Rempe, D. M., \& Dietrich, W. E. (2018). Direct observations of rock moisture, a hidden component of the hydrologic cycle. Proceedings of the National Academy of Sciences, 115(11), 2664-2669.

Rodriguez, M. Z., Comin, C. H., Casanova, D., Bruno, O. M., Amancio, D. R., Costa, L. D. F., \& Rodrigues, F. A. (2019). Clustering algorithms: A comparative approach. PloS one, 14(1), e0210236.

Sawicz, K., T. Wagener, M. Sivapalan, P. Troch, and G. Carrillo (2010), Catchment classification: Empirical analysis of hydrologic similarity based on catchment function, Hydrol. Earth Syst. Sci. Discuss., 8, 4495-4534.

Schwanghart, W., Scherler, D. (2014): TopoToolbox 2 - MATLAB-based software for topographic analysis and modeling in

Selby, M.J., (1987), Rock slopes, in Anderson, M. G., and Richards, K. S., Slope Stability, Chichester, John Wiley \& Sons, p. 475-504. 
https://doi.org/10.5194/hess-2021-228

Hydrology and

Preprint. Discussion started: 10 May 2021

(c) Author(s) 2021. CC BY 4.0 License.

575 Sickman, J. O., Melack, J. M., \& Stoddard, J. L. (2002). Regional analysis of inorganic nitrogen yield and retention in highelevation ecosystems of the Sierra Nevada and Rocky Mountains. In The Nitrogen Cycle at Regional to Global Scales (pp. 341-374). Springer, Dordrecht.

Sivapalan, M. (2006). Pattern, process and function: elements of a unified theory of hydrology at the catchment scale. Encyclopedia of hydrological sciences.

Sollins, P., \& McCorison, F. M. (1981). Nitrogen and carbon solution chemistry of an old growth coniferous forest watershed before and after cutting. Water Resources Research, 17(5), 1409-1418.

585 St. Clair, J. S., Moon, S., Holbrook, W. S., Perron, J. T., Riebe, C. S., Martel, S. J., ... \& Richter, D. D. (2015). Geophysical imaging reveals topographic stress control of bedrock weathering. Science, 350(6260), 534-538.

Thompson, S. E., C. J. Harman, P. A. Troch, P. D. Brooks, and M. Sivapalan (2011), Spatial scale dependence of ecohydrologically mediated water balance partitioning: A synthesis framework for catchment ecohydrology, Water Resour. Res., 47, W00J03, doi:10.1029/2010WR009998.

Tokunaga, T. K., Wan, J., Williams, K. H., Brown, W., Henderson, A., Kim, Y., ... \& Dong, W. (2019). Depth-and timeresolved distributions of snowmelt-driven hillslope subsurface flow and transport and their contributions to surface waters. Water Resources Research, 55(11), 9474-9499.

Uhlemann, S., B. Dafflon, H.M. Wainwright, K.H. Williams, B. Minsley, K. Zamudio, B. Carr, N. Falco, C. Ulrich, S. Hubbard, Shale bedrock variability correlates with surface morphology and vegetation distribution, and controls hydraulic properties, submitted to Scientific Advances.

600 Yan, Q., Wainwright, H., Dafflon, B., Uhlemann, S., Steefel, C. I., Falco, N., ... \& Hubbard, S. S. (2021). Hybrid data-modelbased mapping of soil thickness in a mountainous watershed. Earth Surface Dynamics Discussions, 1-23.

Ye, M., Meyer, P. D., Lin, Y. F., \& Neuman, S. P. (2010). Quantification of model uncertainty in environmental modeling. Stochastic Environmental Research and Risk Assessment, 24(6), 807-808.

605

Wagener, T., M. Sivapalan, P. Troch, and R. Woods (2007), Catchment Classification and Hydrologic Similarity, Geogr Compass, 1(4), 901-931, doi:10.1111/j.1749-8198.2007.00039.x. 
https://doi.org/10.5194/hess-2021-228

Preprint. Discussion started: 10 May 2021

(c) Author(s) 2021. CC BY 4.0 License.

Wainwright, H. M., Dafflon, B., Smith, L. J., Hahn, M. S., Curtis, J. B., Wu, Y., ... \& Hubbard, S. S. (2015). Identifying 610 multiscale zonation and assessing the relative importance of polygon geomorphology on carbon fluxes in an Arctic tundra ecosystem. Journal of Geophysical Research: Biogeosciences, 120(4), 788-808.

Wainwright, H. M., Steefel, C., Trutner, S. D., Henderson, A. N., Nikolopoulos, E. I., Wilmer, C. F., ... \& Steltzer, H. (2020). Satellite-derived foresummer drought sensitivity of plant productivity in Rocky Mountain headwater catchments: spatial

615 heterogeneity and geological-geomorphological control. Environmental Research Letters, 15(8), 084018.

Wan, J., Tokunaga, T. K., Williams, K. H., Dong, W., Brown, W., Henderson, A. N., ... \& Hubbard, S. S. (2019). Predicting sedimentary bedrock subsurface weathering fronts and weathering rates. Scientific reports, 9(1), 1-10.

620 Wood, E. F., Roundy, J. K., Troy, T. J., Van Beek, L. P. H., Bierkens, M. F., Blyth, E., ... \& Gochis, D. (2011). Hyperresolution global land surface modeling: Meeting a grand challenge for monitoring Earth's terrestrial water. Water Resources Research, $47(5)$.

Zamudio K.D., Minsley B.J., and Ball L.B, 2020, Airborne electromagnetic, magnetic, and radiometric survey, upper East 625 River and surrounding watersheds near Crested Butte, Colorado, 2017: U.S. Geological Survey, https://doi.org/10.5066/P949ZCZ8. 